\title{
Whistleblower protection needed in Canada: advocates
}

Recent scandals involving scientists and doctors, drug companies and governments illustrate the need for stronger whistleblower protection in Canada, public interest advocates contend.

Current legislation in Canada is inadequate, says the Canadian Health Coalition, a health care advocacy group. If health care workers are to carry out their duty to protect patients, they must be free to go directly to an agency and remain anonymous, says Michael McBane, the Coalition's national coordinator.

"If employees have to go through their superiors before they are allowed to speak, it makes public employees more vulnerable to reprisal," says McBane. That's particularly risky when the supervisors themselves are involved in wrongdoing, he says.

Bill C-25, which would have provided some whistleblower protection, died on the order paper when the federal election was called this spring. But it offered little in genuine protection anyway, says Duff Conacher, coordinator of the advocacy group Democracy Watch. The bill did establish an agency to which whistleblowers could turn, but did not allow anonymous reporting, a critical element, Conacher says.
The groups' concerns are underscored by the recent firing of 3 Health Canada scientists (see page 438) and the results of a 2001 inquiry into the deaths of 12 infants at a Winnipeg hospital. The inquiry found 5 of the infant deaths might have been prevented (CMAF 2001; 165 [9]:1242) and recommended whistleblower protections to protect nurses from reprisals and encourage them to report irregularities.

Rewards should also be incorporated in legislation, says Conacher, since whistleblowing often kills careers. Successful whistleblower suits can pay off for governments, the public and the whistleblower, he says.

When David Franklin, a medical liaison for WarnerLambert, filed a whistleblower lawsuit against his company, he became eligible under the US False Claims Act for an award of $15 \%-30 \%$ of any amount the government recovered. Franklin discovered his company was illegally promoting off-label uses of gabapentin (Neurontin); such use accounts for up to $90 \%$ of the drug's use.

The case was settled on May 13 when the company pleaded guilty to civil and criminal charges of using "fraudulent scientific evidence" to promote off-label uses of gabapentin. Pfizer agreed to pay \$240 million; Franklin will receive \$24.6 million of that sum. The rest will go to Medicare and Medicaid to reimburse excess payments for the purchase of gabapentin, and to agencies helping patients treated inappropriately with the drug.

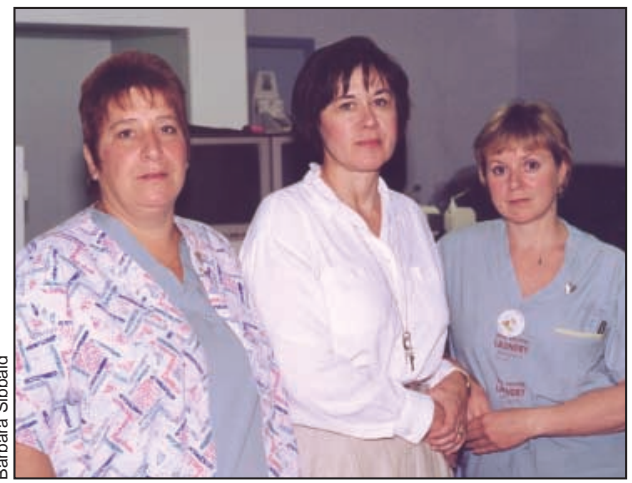

Winnipeg whistleblowers: Nurses Irene Hinam, Carol Youngson and Carol Bower spoke out about high death rates.

Effective whistleblower legislation should help provide job security and "create a climate in which workers feel encouraged to report problems in the workplace, instead of feeling that raising concerns will result in a backlash," says Doreen Meyer, spokesperson for the Canadian Union of Public Employees. Jeanne Lenzer, Kingston, NY

\section{Holiday Review 2004 Call for Papers}

We're looking for creative contributions for CMAJ's Holiday Review 2004. Humour, personal reflections, history of medicine, off-beat scientific papers and postcards from the edge of medicine are welcome.

Send your offering to the Managing Editor, Josephine Sciortino (800 663-7336 x2366; josephine.sciortino@cma.ca). Articles should be no longer than 1200 words, and photographs or illustrations are encouraged.

The deadline for submissions is September 13, 2004.

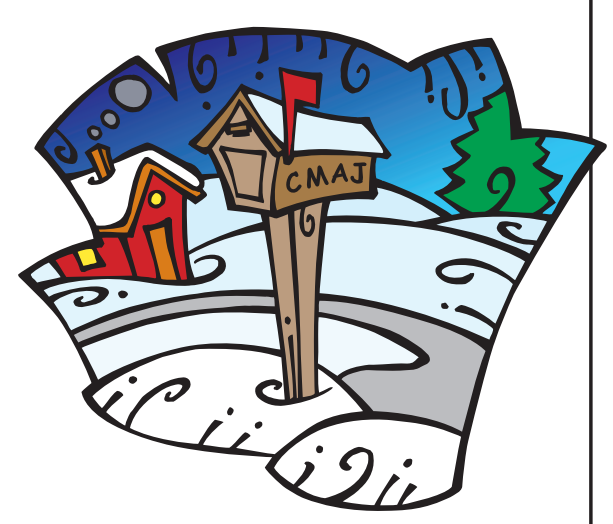

